\title{
Peace and Welfare in the Semurup Malay's Proverbs in Kerinci
}

\author{
EDIZAL HATMI, IKHWANUDDIN NASUTION, ASMYTA SURBAKTI, EDDY SETIA \\ Post Graduate Department of Linguistics, \\ Faculty of Social Sciences, University of Sumatera \\ Utara,Medan, Indonesia;
}

\begin{abstract}
:
Objectives: The research is aimed at exposing local wisdom of peace and welfare in community proverbs of Kerinci's Malay Semurup to be socialized and used as the philosophy of life so that the cultural heritage will not be extinct.

Method: The method used in the research and study of cultural values as a source of local wisdom contained in the expressions (proverbs) of the Semurup Malay community is qualitative descriptive research method combined with quantitative method to construct the reality of cultural values as a source of local wisdom in the expressions of community proverbs.

Findings: The research result shows that there is a significant change, that people who understand the elements of local wisdom increase to $8.75 \%$ or 20 people, people of moderate ability 4 or $1 \%$, and of low-ability descends to 1 person or $0.25 \%$.

Improvements: The culture of Semurup Malay community of Kerinci is known for being friendly, polite, harmonious, open, and always prioritizing public above personal and group (tribal) interests. This philosophy now begins to fade by the changing of times. This also causes the decline of dignity and standing of the ninek mamak as the custom stakeholder in the eyes of community, and eventually the sacred values of the customs will disappear unless some efforts of preservation are done.
\end{abstract}

Keywords: Community proverbs, Local wisdom, Peace and welfare

\section{Introduction}

One of the cultural elements in the literary works which is less appreciated refers customs. As part of oral tradition of a community, customs serves as a tool to organize and regulate people's lives in socializing and interacting with one another in the same environment. The tool or media used as the guidance of community life is customary law. The Malay Community of Semurup, Kerinci in the past in the process of structuring kinship and kinship ties always refers to the system applied to local customs. The system that governs the life of this society is called by the term of terombocontaining three main points: (1) ajun arah or 'territorial division' system, (2) family tree, (3) customary rules and law. The subject matter that will be parsed in this study is about law and customary law.

Customary law is a rule or provision that serves as a binding tool for every individual or citizen in a community group. This customary law is used as a guide, order, and controlling tool in behaving. Meanwhile customary law is a tool (law) used by the ninik mamak or custom stakeholders to decide a case in the community. Customary act and customary law are passed down orally with the same structure and meaning. Such a system of inheritance is called adat ngaji, though some of the expressions in customary act and law are sometimes no longer suitable for a culture at a certain given time. For example, in the customary law of the Malay community of Semurup, Kerinci, the phrase " kiluk paku kacang balimbing, tempurung lenggak lenggokkan 'lekuk paku (pohon pakis) kacang belimbing, tempurung dilenggak-lenggokkan' is more concerned with the welfare of life of nephew than the welfare of one's own children. This philosophy is based on the Malay tradition of Semurup Kerinci who agrees 
that the successor of the family is the nephew, who becomes the foundation of the family's hope to raise the family's dignity.

The above phrase is no longer fully applicable in the context of Malay community of Semurup Kerinci today. The intensity of this principle has been rare to be implemented or put in the second place and even tended to be no longer adopted or applied in everyday life by the community today. This element in the past is considered sacred and must be obeyed, and implemented by every individual in the community. The change of community view is caused by many factors such as education, association, assimilation, media, and technology. The nature of Melayu Semurup Kerinci people who like to wander and are very open in receiving immigrants also influence the way of view and the mindset of comunity and will eventually also affect the customs, traditions, and local culture, so that individualistic manners tend to be more highlighted, or in other words the Malay community of Semurup Kerinci is more concerned with themselves and their families than relatives today.

The above philosophy that has been the guidance of life for the Malay Semurup Kerinci community is not only changed in the family life order, but also penetrated into the social life of the community. The Malay community of Semurup Kerinci, once famous for being friendly, polite, and living in harmony (always putting the interests of the people above self-interest) is now fading away by the changing times. This also causes the decline of dignity of the ninek mamak party as custom stakeholders in upholding customary act and law in the eyes of the people, and in the end the cultural sacred values (local wisdom) of the customs will also disappear. According to Djamaris (2002: 248) in Agustina, et al (2016) just like other eastern peoples, Minangkabau people appreciate people who are hospitable, humble, courteous and dislike people who are irritating and arrogant.

Local wisdom can be interpreted as a result of the thinking of the local community based on real events that occur in everyday life. This thought is used as a medium to overcome various problems in the community. The search for local wisdom in the community expressions (proverbs) is the of focus of the study. It aims to preserve and maintain a valuable oral tradition. The next stage to be done is a reconstruction so that the culture of this nation will keep existing.

Based on the description above it can be understood that the community expressions (proverbs) contain noble values and cultural norms called the local wisdom that serves to guide, organize, and the community life in interacting or socializing with the environment to create peace. In addition, the community expressions in the form of proverbs are also a reflection of the people's desire for a future expectation in order to create a peaceful and prosperous life.

By this it is seen that Local wisdom is a cultural product of society in the past containing the values of attitudes, such as values of democracy, leadership, respecting guests, keeping promises, mutual cooperation, respecting parents, and avoiding clashes. Such values of attitude should be constantly maintained, preserved and revitalized to be used as a guidance of life, especially for the present generation easily influenced by strange culture. In spite of being local in nature, the values are considered universal, if implemented and will be able to fix the attitude and become a controlling tool in behaving in the community environment.The local wisdom can also be used as a basis for decisionmaking at the local level to solve various social problems in society. Furthermore, if local wisdom is focused on cultural values, it can also be defined in other ways that local wisdom is the value of local culture that can be utilized to regulate the structural life of community wisely. The same thing is proposed by Apriyanto, (2008) dalam Alus (2014:2) that local wisdom is a range of values created, developed and preserved by people to be guidelines in life.

The local wisdom has been integrated with the belief system, norms, customs, and culture, and has been expressed in the tradition adhered to for a long time. According to Sibarani (2012: 112) local wisdom is 
the indigenous wisdom or knowledge of a community derived from the noble value of cultural traditions to regulate the life order of society.

For the Malay society of Semurup Kerinci the concept of values, ethics, and morals are derived from the teachings of religion, but long before religion comes to the realm of Kerinci, people have recognized the concept of values, ethics and morals through local culture (local wisdom) applied in the process of interaction with others called etiquette. Local wisdom is also used by the community as a guide to achieving life goals ranging from improving the quality of agricultural systems, work ethics, balance, and harmony with nature, and social system. In terms of social system harmony and harmony, the Malay of Semurup has long mixed up the principle of mutual cooperation and tolerance in terms of maintaining the balance. Keraf in Surur et al (2014) asserts that local wisdom is all forms of knowledge, belief, understanding or insight and customs or ethics that guide human behavior in the ecological community.

The local wisdom mentioned above is a legacy of the past passed down by the ancestors to the present generation, basically not only in traditional literary works (oral literature) as a reflection of the community speaker, but also in various areas of life, such as: philosophy, life view, health, folk art, and architecture. This high cultural value will be extinct, if there is no party willing to conduct the process of preservation, reconstruction, and revitalization of this local wisdom.

\section{Concept Headings}

The method used in the research is qualitative descriptive research combined with quantitative research method. Qualitative research assumes that reality has multiple dimensions and there is an exchange of social experiences interpreted by each individual. Truth is believed to be dynamic and can be found only through the study of people through their interaction with the social situation in their environment. This is similarly expressed by Usman and Akbar (2006) in Juniarta, et al (2013: 13) "Qualitative methods try to understand and interpret the meaning of an interaction event of human behavior in certain situations". Quantitative method is used to see the level of public understanding of the results of research, so that changes in the level of understanding of local wisdom in the phrase (proverb) before and after the process of socialization could be seen clearly.

The flow of this research is based on the idea that the expression (proverb) consists of reality of cultural values as shown in Figure 3.1 below. 
Figure 3.1: Model of Research Application on Text of Semurup Malay Proverbs

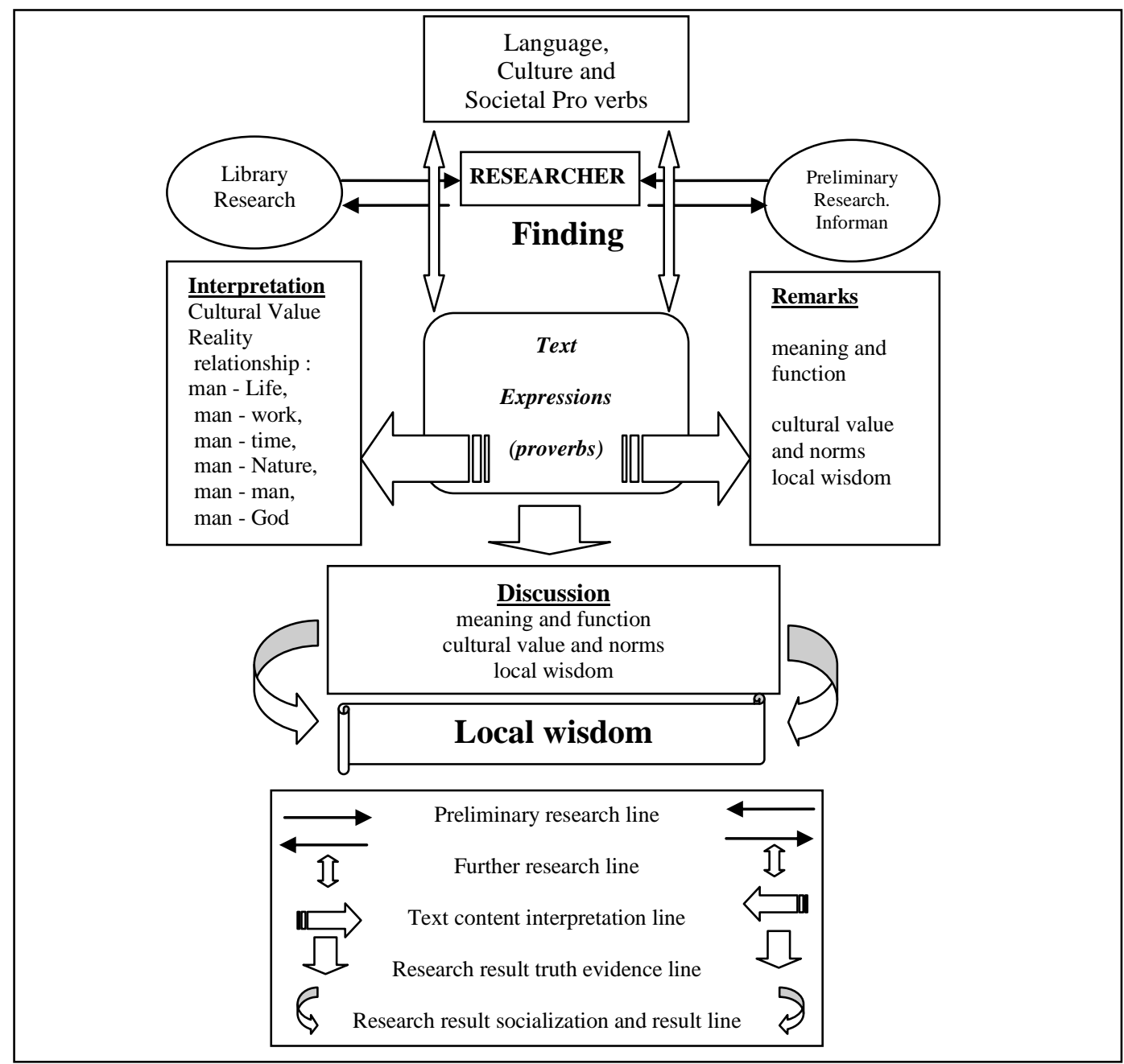

\section{Local wisdom socialization}

Based on Figure 3.1 above it can be stated that there are seven stages in the study of the expression (proverb), based on the process of interpretation, meaning, and verification. The five stages consist of preliminary research, interpretation of cultural values, explanations of meaning and function, formulation of research results, discussion of research findings, relevance of research findings to the life of the Malay community of Semurup Kerinci in the present, and socialization of research results in the element of local wisdom as a reference or life view of community that can be passed on to the next generation as the identity and character of the nation.

In details the five stages of the research are as follows:

1. The preliminary research is conducted as the first step in the process of maturation of research preparation by reading the written text which has relevance to the research material, then the researcher conducts discussion with informant in details, as the source of research data. The reading is done by tracking the written data that once existing in the community, as well as tracking printed materials in the form of books and journal articles. Thus, the researcher gets enough insight before continuing the research.

2. The interpretation of the reality of cultural values in the expression as a source of local wisdom is the first part of further research. The interpretation systematizes the life events of the Semurup Malay people in terms of the relationship between man and life, man with work, man with time, man with nature, man with man, and man with God. After the interpretation process has been completed, this 
section will also explain things related to the meaning and function of the text, cultural values and norms, and local wisdom contained in the expression (proverb) of community.

3. Formulating the findings of the interpretation of the content of the text of the expression (proverb) as a research finding that has the potential to be socialized in the Kerinci Semurup Malay community.

4. Discussion of research findings into subsequent targets of research combining the findings of research results with the results of the process of interpretation of the phrase (proverb). The discussion details the elements of local wisdom contained in the literary text of the expression (proverb) of community. The findings of the research and the research findings will be of relevance in real life in the current Semurup Malay society. This aims to facilitate the researcher to create a framework of cultural socialization and local wisdom contained in the research results

5. The last stage in this research is the process of socializing local wisdom contained in the phrase (proverb) to the community by giving counseling or socialization directly in groups. To see the level of public understanding of research findings about local wisdom, the researcher conducted a process of counseling or direct socialization for two-time meetings. The sample population was taken randomly from three villages. Village Koto Mudik Semurup 7 people, New Village Semurup 10 people, and Village Koto Tengah Semurup 8 people, so the number of samples are 25 people. To see the improvement of the community's ability to understand local wisdom, then the initial test and the final test were done. Cultural values that become the source of local wisdom is expected to be a reference, speech, and rules for the community owners in living a life in the community called the character of bangasa. The results of this research socialization will also be expected to be a learning material for the next generation as a form of the nation's character.

\section{Results and Discussion}

\subsection{Cultural Values in Community Expressions (Proverbs)}

Cultural values in proverbs adhered to can be sorted into man-life; man-work; man-time; man-nature; man-man; man-God relationships. The man-life relationship expresses the expression or meaning (information) that is guided by human and has good values. The man-work relationship expresses human activity expressed through the expression referred to in the proverb. The relationship of time, nature, man-and-man, and God is guided owing to good values. Human relationships referring to life, work, time, nature, man-and-man, and God can be evaluated one by one. Pertaining to this the study is limited to two proverbs representing each type of relationship.

\section{A. Man-Life Relationship}

Proverbs adhered to and related to man-life relations can be seen in the following data.

(01) Lain adat lain lembagonyo

different place, different customs/rule; adjustment to environment.

(02) Sekali mundayung duo tigo pulau terlampaui

Once rowed two three islands exceeded 'Once work gets multiple benefits'

Data (01) lain adat lain lembagonyo 'different place, different customs/ rule; adjustment to environment. This proverb tends to be addressed to a new person moving or occupying a new area then he must be able to adapt himself to the surrounding environment. This means that a person who has just moved or occupied a new territory / area, must submit to and obey the rules in the local area; if there are activities related to the mutual cooperation (the community) he must involve himself . In this part of the maxim the element of local wisdom can be taken; that is 'obedience; obedience to a commitment and rules applied in the community.

Pada data (02) Sekali mundayung duo tigo pulau terlampaui Once rowed two three islands exceeded 'Once work gets multiple benefits', is a proverb that refers to someone who has a smart idea and willing to work hard so that he will get success beyond expectation. This proverb means 'wisdom', in the sense that such a person is capable of managing a large, heavy, and large work into a light, efficient, and 
effective, one. Elements of local wisdom that can be drawn are: smartness, wisdom, simplicity, efficiency, and efficiency.

\section{B. Man-Work Relationship}

The man-work relationship adhered to can be understood as a picture of good values of work. Data of proverbs showing the man-work relationship are:

(03) tibo tampak muko pegi tampak punggung : coming showing face and going home showing back; meaning that a person should ask or says greeting in time of coming or going.

(04) sekepa demi sekepa : Segenggam demi segenggam 'sedikit demi sedikit lama-lama menjadi bukit'

The proverb (03) tibo tampak muko pegi tampak punggung : coming showing face and going home showing back; meaning that a person should ask or says greeting in time of coming or going.

This shows courtesy in man-work relationship. Anytime we come to a place, our coming should be known by the host; so as when we return, also to be known by the host. This is a manifestation of etiquette or courtesy) that has become part of the daily life of the people from the ancestors to the present generation. Elements of local wisdom that can be derived from this proverb are (1) courtesy, and (2) ethics. The proverb (04) little by little refers to the work (activity) of man so that his work is satisfactory. Activities require patience, perseverance, and tenacity in each individual to produce something very exciting and satisfying. . Elements of local wisdom that can be derived from this proverb are patience, perseverance, and tenacity.

\section{Man-Time Relationship}

The proverb adhered to is concerned with the relationship of man and time containing virtues to be used as a guidance in community life, as presented below:

(05) Buibu ku waktu bubapak ku zaman: having wide horizon to be adjusted with the progress of time.

(06) Waktu tapian uang: time is the source of wealth; every activity will surely give something good and precious.

Proverb (05) concerns the question of time in human activity. Man is related to time in cultures (doing activity). This relationship includes a broad insight because humans must adjust to time in various activities and circumstances. In this proverb we are taught to understand the philosophy that can be used as a guidance of life that time is a good guideliness and can provide many things in life to lead us to maturity in running our life. In the data (06) Waktu tapian uang shows that time is source of wealth implying that time has great values and time should be filled with useful activities so that will be useful for the person concerned. Time interpreted as a source of wealth also suggests that every human being should be able to utilize and maximize the best time possible to prepare a better life for tomorrow. Both of these man and time relationships are adhered to because humans actually have insight and can adapt themselves to time. Elements of local wisdom that can be derived from this proverb are selectiveness, introspectiveness, and carefulness.

\section{Man-Nature Relationship}

The man-nature relationship in this proverb concerns the relationship between man and the natural surroundings that can be adhered to as something of good value. This relationship can be a comparison of inanimate objects, animals, plants, or other natural events.

The data referring to this are:

(08) lain ladang lain pulo tapiannyo

self-adjustment

(09) nyaring kukuk

shrill voice

agreement 
The two data above show the relationship of man and nature; the first data (08) lain ladang lain pulo tapiannyo refers to human activity in fulfilling the necessities of life by utilizing nature as a place to make a living. Semurup Malay community believes that every inch of nature has a keepers or inhabitants respectively, so that there is no dispute or friction among creatures of God's then there must be an ordinance before expanding or processing new land. Habits of people that have been rooted at the time of opening a new agricultural land (clearing the forest) is initiated by asking permission. The process of asking permission is usually followed by several conditions including the laying of betel, gambier, areca nut, and burning white whisk accompanied by chanting prayers. This is done so that the forest guards who firstly inhabit the area do not feel disturbed by our presence. Therefore, everyone must be able to adjust himself to the circumstances and regulations surrounding nature, both social life and life.

In the example (09) nyaring kukuk 'seia sekata/firmness refers to the action of man who must equate his actions and behaviors with the natural surroundings firmly or consistently, in particular with the rules and norms set by his community. Elements of local wisdom that can be derived from this proverb are honesty, politeness, respectfulness, respectful, friendliness, caring, consistence, and reflection

\section{E. Man-Man relationship}

Man and man relationship in the proverb concerns human relationships that can be adhered to as something of good value. This relationship can be a composite of a story, a human behavior, an animal, or an event. Data referring to this are as follows.

(10) bak gulo dingan semut

always being together

harmonious pair

(11) Busatu kito teguh bucerai kito rubuh

mutual assistance and unification

These two data show the relationship of man and man, the first (10) ) bak gulo dingan semut or harmonious pair' is a proverb referring to a matching pair between a woman and a man. This proverb refers to a pair of lovers or spouses, where both couples must always coexist in order to complete each other, and cover each other's deficiencies with a sense of love and loyalty. The second proverb (11) refers to unity and unification in the family, tribe, and nation so that a strong unity is formed and cannot be scattered by any force that tries to disturb it. Based on the above proverb, it can be drawn that the elements of local wisdom are loyalty, unity, togetherness.

\section{F. Man-God Relationship}

The man and God relationship in the community expression (proverbs) is concerned with human relationships with His creator (God). This relationship is the adjustment of the actions and the mind of man with the provisions set by God. Data referring to this are as follows.

(12) Nan tacurek dari langit

anything poured from Heaven

blessing/destiny

(13) asik pelaho

seriously keeping

trust

The two data above show the human relationship with God, the first (12) nan tacurek dari langit blessing / destiny' is a proverb that initially refers to the erroneous human activity and has been recorded by his deeds of angels. Therefore, every human being is forbidden to sin. Nan tacurek dari langit poured from Heaven//blessing/ destiny', shows acts or mistakes committed by a person will be judged according to the laws that have been established and poured from the sky (by Allah). The duty of man is to ask 
forgiveness from God for all the sins and mistakes of the past, based on guilt and solemn plea, and God will probably give forgiveness and guidance to those whom He pleases. This proverb does not mean that the wrong action is adhered to but made into consideration so as not to perform such action again.

In the sample data (13) asik pelaho is a proverb referring to human activity in performing duties as a caliph who receives the mandate or responsibility of God to keep the earth / nature in order to remain sustainable. The word asik can be interpreted as a very pleasant word or deeds done with pleasure or joy, while the word pelaho can be interpreted as nurture, and if these two words are combined it can be interpreted as an activity in maintaining and preserving the universe or in other words a sense of happiness in performing duties as caliph to preserve nature. Elements of local wisdom that can be taken from the proverb are obedience, humility, politeness, patience, respectfulness, friendliness, caring, consistence, trustworthiness, , contemplation, and trust.

\subsection{Local Wisdom for the Welfare}

Part of a culture that greatly affects people's attitudes and behavior is a system of beliefs, , superstitions, myths, knowledge, and habits. A development programs in a region often fail because people do not pay attention and understand cultural factors in society. To improve the welfare of the people and reduce poverty for example, cannot only rely on one side of the perspective, but must also understand other aspects such as: knowledge, , beliefs, and habits of society. Specifically the welfare is judged from lack of income, consumption, ownership of both stationary and moving property, capital and stock assets. The value of minimum poor household income is less than $1920 \mathrm{~kg}$ equivalent of rice per household per year (Sayogyo, 1978; Tjondronegoro, Soejono \& Hardjono, 1996; van Oostenbrugge, van Densen \& Machiels, 2004) in Pattinama (2009: 3).

Utilizing existing concepts in local community knowledge is not something too naive to try and tested comprehensively for development. All the institutions in people's lives have local wisdom that can be utilized for the common good. Local wisdom in the expressions (proverbs) Semurup Malay Kerinci is rich, and this is to be used as a pillar to boost the welfare of the community. To realize the welfare of the community by utilizing local wisdom as a pillar, is not as easy as turning the palm of the hand. However, it should involve all elements of society and supported by the local government.

The local wisdom in the expressions of community expressions (proverbs) that can be used as medium to improve the welfare of society are as follows: (1) hard work, (2) glory, (3) dexterous, (4) tenacity, (5) smartness (6) conscientiousness (7) perseverance (8) having wide scope of thought, (9) persistence, (10) discipline, (11) steadfastness, (12) patience, (13), responsiveness, (14) loyalty, (15) inspirational, (16) ) mutual cooperation.These sixteen points of local wisdom can be used as a philosophy to improve the lives of the people. This is because the local wisdom has a philosophy of high value.

Reflecting on the local wisdom mentioned above then there is no single cultural norm that is able to let other relatives starve. In the Malay cultural philosophy of Semurup Krinci, no Semurup family is capable of letting relatives abandoned; they have to help each other with strong family ties and that is the local wisdom to be preserved.

\subsection{Local Wisdom for Peace}

Reality that is always present along with the dynamics of social life of a society is conflict that can occur both among individuals and groups. Therefore, a conflict in the social life of the community is difficult to avoid. The presence of conflict in the midst of society if cannot be managed properly will cause social impacts for the community, while the impact is the hampering process of development both of infrastructure resources human. Today the most vulnerable social problems in Semurup Malay Kerinci are horizontal conflicts such as issues related to moral crisis, ethics, promiscuity, inter-tribal dispute or heart, inter-village dispute. 
If this problem is not addressed wisely and comprehensively then the conflict will be dissolved which will ultimately harm the community itself. Some of the recent inter-village disputes are initiated by trivial matters such as misunderstanding among youths (mockery), then developed into fights, eventually spreading into inter-village conflicts. This dispute certainly not only takes casualties, but also the property of both sides of the community, so such problems need to get serious attention from all elements of society, the government and everyone must find the right solution so that the conflict does not develop or keep going.

If togetherness and brotherhood are not built properly then power and the thought will be drained off and the local government will have difficulty in implementing the development program of village infra-structure, and in the end the government cannot improve the welfare of the people domiciling in the area. To solve the recent social problems in the Malay community of Semurup Kerinci is by building a strong commitment from within the society itself, by promoting local wisdom approach which is in accordance with the character and anatomy of each local area, then trying to optimize the role of community leaders in the region, besides not ignoring the legal norms applied as a consequence of the violation of norms as a counterweight in the social life of society. Conflict must be abandoned and fought as an enemy of civilization for the Malay community of Semurup Kerinci.

In addition to the theoretical model of solving social problems as a result of empirical studies, it should be remembered that communities have a diversity of values, systems, power structures, resource management models and distinctive patterns of change. This will also give effect to the form of settlement that is considered appropriate for the community. Each region has its own wisdom in addressing the problems, including the ways a particular group or community solves social problems they face or often referred to as local wisdom The issue of local wisdom into problem solving solutions is often ignored, considered irrelevant to the present or the future. The impact is many cultural values and good habits to be maintained as a way to make changes are ignored.

The local wisdom in the expressions of community expressions (proverbs) that can be used as medium to improve the welfare of society are as follows: (1) hard work, (2) glory, (3) dexterous, (4) tenacity, (5) smartness (6) conscientiousness (7) perseverance (8) having wide scope of thought, (9) persistence, (10) discipline, (11) steadfastness, (12) patience, (13), responsiveness, (14) loyalty, (15) inspirational, (16) ) mutual cooperation. While local wisdom in the expressions of society (proverbs) that can be used as a medium to maintain peace in society are as follows: (1) social solidarity, (2) harmony, (3) wisdom, (4) hospitality, (5) ethics (6) politeness (7) having wide scope of thought (8) consensus (9) faithfulness, (10) mutual cooperation, (11) sincerity , (12) accepting destiny, (13) prudence, (14) glory, (17) unification, (18) inspirational, (20) coolness, (21) peace, (22) humility, (23) self-awareness, (24) tranquility, (25) ) Introspection, (26) reflections, (27) compassionate, (28) accepting fate, (29) obedience (30) piety, (31) mutual cooperation, and (32) trust worthy.

At this stage, when humans with modern ratios have been confused with the nature and behavior of society, the local wisdom will get its place back. In reality harmony with nature and environment can guarantee the future of human beings. It has, of course, been proved through a long process of ancestral life in local communities to anticipate nature through wise cultures. The distinctive social issue in Semurup Kerinci is the inability of scientific knowledge to get in touch with social management and ultimately the local wisdom becomes the only hope of solution.

\subsection{Socialization Result of Local Wisdom}

The process of local wisdom socialization as a result of research and in-depth assessment of the community expressions (proverbs), was done to the Malay community of Semurup Kerinci by setting a sample of 25 people consisting of 15 men and 10 women from three villages. 


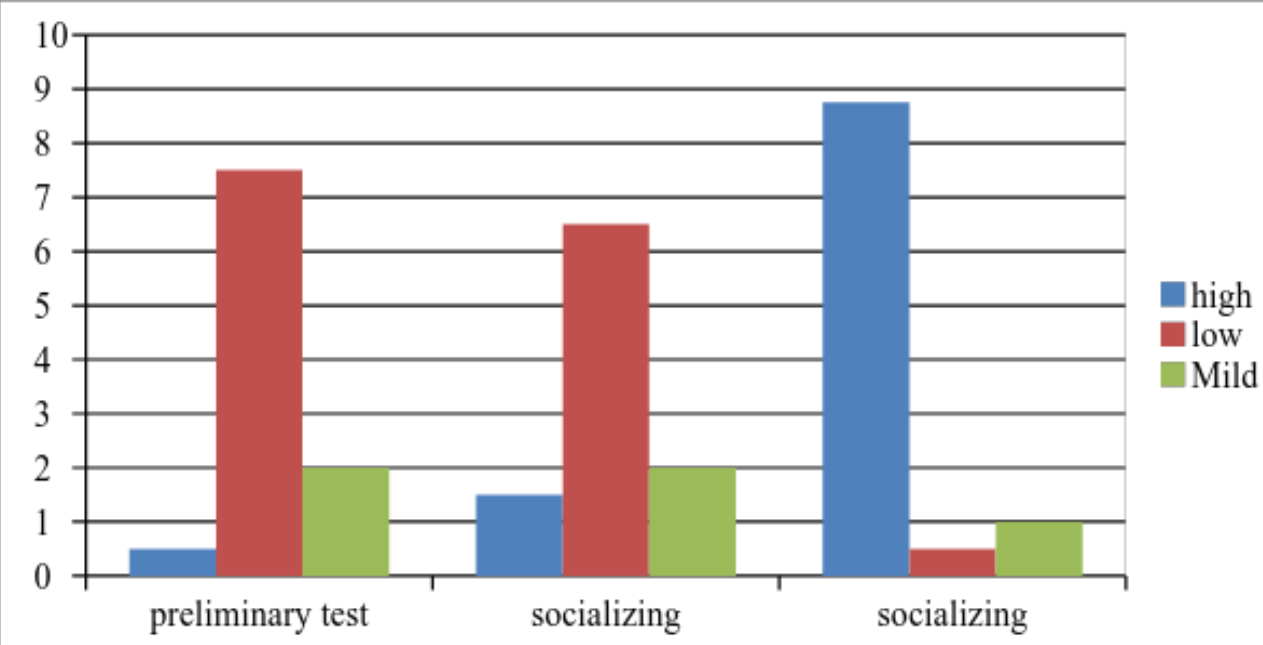

Figure 3.2 : diagram tem of the understanding of local wisdom

Based on the figure above it can be explained that the test results in the early stages of understanding the community towards the elements of local wisdom contained in the expressions (proverbs) can be explained as follows: a community that is high in understanding the elements of local wisdom only 2 people or $0.5 \%$ Moderate ability 8 people or $2 \%$, while low-ability of about 15 people or $7.5 \%$. Based on preliminary test results it can be concluded that it is necessary to conduct socialization activities to increase public understanding of the importance of local wisdom as a guidelines of life. The results of the test after the extension activity 1 shows an increase in community understanding compared to previous understanding. Based on the figure above it can be stated that the high-ability community rose to 6 people or $1.5 \%$, capable of staying in the position of $2 \%$, and the low-ability down to $6.5 \%$. To increase the community's understanding of the importance of local wisdom as the joints of life, the second stage of socialization or counseling is done. After the second stage of the counseling process, a test is conducted to see the change in the ability of the community. The results can be stated in accordance with those seen in Figure 3.2 above. Based on the figure above it is clear that there is a significant change, people who understand the elements of local wisdom increased to $8.75 \%$ or 20 people, moderate to 4 people or $1 \%$, and low-ability down to 1 person or $0.25 \%$.

\section{Conclusion}

Based on the findings, descriptions, studies, and analysis on the content of the community's expressions (proverbs) and seeing its relevance to the life of the Semurup Malay Kerinci community, it is found that the elements of local wisdom are contained in the expressions of community (proverbs). Cultural values (local wisdom) are found getting in touch with a good understanding of the community. In details research findings on cultural values are the relationships of man with life; man with work; man with man; man with nature; man with time and man with God.

The local wisdom in the expressions of community expressions (proverbs) that can be used as medium to improve the welfare of society are as follows: (1) hard work, (2) glory, (3) dexterous, (4) tenacity, (5) smartness (6) conscientiousness (7) perseverance (8) having wide scope of thought, (9) persistence, (10) discipline, (11) steadfastness, (12) patience, (13), responsiveness, (14) loyalty, (15) inspirational, (16) ) mutual cooperation. While local wisdom in the expressions of society (proverbs) that can be used as a medium to maintain peace in society are as follows: (1) social solidarity, (2) harmony, (3) wisdom, (4) hospitality, (5) ethics (6) politeness (7) having wide scope of thought (8) consensus (9) faithfulness, (10) mutual cooperation, (11) sincerity , (12) accepting destiny, (13) prudence, (14) glory, (17) unification, (18) inspirational, (20) coolness, (21) peace, (22) humility, (23) self-awareness, (24) tranquility, (25) ) Introspection, (26) reflections, (27) compassionate, (28) accepting fate, (29) obedience (30) piety, (31) mutual cooperation, and (32) trust worthy. After the process of socialization, people who 
understand the elements of local wisdom increased to $8.75 \%$ or 20 people, moderate to 4 people or $1 \%$, and low-ability down to 1 person or $0.25 \%$.

\section{References}

1. Agustina, Syahrul, R., Yasnur Asri 2016. Muatan Kearifan Lokal Dalam Cerpen Mutakhir Karya Cerpenis Minangkabau. $\quad$ Vol. $\quad$ XV $\quad$ No. http://ejournal.unp.ac.id/index.php/humanus/article/view/6408/4960. Date Accessed: 3/3/2017

2. Alus, Christeward 2014. Peran Lembaga Adat dalam Pelestarian Kearifan Lokal Suku Sahu di Desa Alisoan Kecamatan Sahu Kabupaten Halmahera Barat. Journal “Acta Diurna” Volume III. No. 4.file:///C:/Users/user/Downloads/5995-11653-1-SM.pdf Date Accessed: 6/4/2017

3. Fadhil, Surur. et.al. 2014. Pertimbangan Aspek Sosial Budaya dan Kearifan Lokal dalam Pengembangan Kawasan Danau Tempe Provinsi Sulawesi Selatan. VOLUME 16 NOMOR 3 UNDIP.http://ejournal.uajy.ac.id/8977/1/5.\%20TATALOKA\%20MAKNA\%20RUANG\%20KAMPUNG.pdf Date Accessed: 5/3/2017

4. Hagi Primadasa Juniarta1 , Edi Susilo2 ,Mimit Primyastanto3.2013. Kajian Profil Kearifan Lokal Masyarakat Pesisir Pulau Gili Kec. Sumberasih Kab. Probolinggo Jawa Timur. ECSOFiM Vol. 1 No. 1, 2013. http://ecsofim.ub.ac.id/index.php/ecsofim/article/viewFile/10/8 Date Accessed: $5 / 3 / 2017$

5. Pattinama, Marcus J. 2009. Pengentasan Kemiskinan dengan Kearifan Lokal (Studi Kasus di Pulau Buru-Maluku dan Surade-Jawa Barat). Aksara, Sosial Humaniora, VOL. 13, NO. 1, JULI 2009: $1-12$ http://repository.ui.ac.id/contents/koleksi/2/e98e701d3488e758e71344d4c5a109bd7770dbd0.pd fDate Accessed: 3/5/2017

\section{To refer a Book/ Report}

1. Sibarani, Robert 2012. Kearifan Lokal, Hakikat, Peran, dan Metode tradisi Lisan. Jakarta: ATL 